IJM

42,2

Received 28 February 2019

Revised 25 October 2019

26 February 2020

5 April 2020

27 April 2020

Accepted 30 April 2020

\title{
Understanding early-stage firm performance: the explanatory role of individual and firm level factors
}

Pi-Shen Seet

School of Business and Law, Edith Cowan University, Joondalup, Australia

Noel Lindsay

University of Adelaide, Adelaide, Australia, and

Fredric Kropp

Middlebury Institute of International Studies at Monterey, Monterey, California, USA

\begin{abstract}
Purpose - This study presents and validates a theoretical model linking individual characteristics of the founding or lead innovative entrepreneur of a start-up venture - the entrepreneur's values, entrepreneurial attitudes and entrepreneurial self-efficacy - to the firm's entrepreneurial orientation (EO) and market orientation (MO) and, ultimately, to firm performance.

Design/methodology/approach - We conducted a survey on a stratified random sample of founders of early-stage South Australian micro- and small enterprises with a response rate of $24 \%(N=204)$. Structural equation modelling was used to evaluate the model.

Findings - The study found that there is a significant relationship between the individual lead entrepreneur and firm strategies developed in early-stage firms in explaining firm performance. It also found that internal values are positively related to entrepreneurial attitude. Entrepreneurial attitude is positively related to entrepreneurial self-efficacy and EO innovativeness. In turn, entrepreneurial self-efficacy is related to innovativeness, proactiveness and risk-taking. The proactiveness dimension of EO and entrepreneurial attitude is related to MO. Entrepreneurial self-efficacy, innovativeness and MO are related to firm performance. Research limitations/implications - This research was limited to entrepreneurial ventures in South Australia and may lack generalisability in other states and countries.

Originality/value - The research contributes to the understanding of the heterogeneity within self-employed individuals, in particular among innovative entrepreneurs, by expanding insights regarding antecedents and consequences of the entrepreneurial process. It develops insights into the links of individual-level constructs with firm-level constructs to develop a more meaningful understanding of new venture creation and performance. It enhances our knowledge of the heterogeneity within the group of self-employed by exploring the individual entrepreneurial antecedents of performance in early-stage firms.
\end{abstract}

Keywords Self-employment, Antecedents, Consequences, Early-stage ventures, Values, Entrepreneurial attitude, Entrepreneurial self-efficacy, Entrepreneurial orientation, Market orientation, Firm performance

Paper type Research paper

\section{Introduction}

Though the statistics vary across countries and cultures, typically, less than one-third of new businesses survive more than five years (Timmons and Spinelli, 2007), especially for start-ups operating and competing in global markets (Nummela et al., 2016). There are numerous reasons for failure including macroeconomic conditions, competition, poor market selection, a flawed business model, an inadequate team and poor cash flow. Some of these factors are

(C) Pi-Shen Seet, Noel Lindsay and Fredric Kropp. Published by Emerald Publishing Limited. This article is published under the Creative Commons Attribution (CC BY 4.0) licence. Anyone may reproduce, distribute, translate and create derivative works of this article (for both commercial and non-commercial purposes), subject to full attribution to the original publication and authors. The full terms of this licence may be seen at http://creativecommons.org/licences/by/4.0/legalcode.
International Journal of Manpowe Vol. 42 No. 2, 2021 pp. $260-285$

Emerald Publishing Limited 0143-7720

DOI 10.1108/IJM-02-2019-0112 
environmental; others are factors associated with the founder or lead entrepreneur and the firm itself. In their influential paper, Low and MacMillan (1988) note that entrepreneurship occurs at different levels (individual, organisational and/or aggregate levels) and that it is important that entrepreneurship research be conducted at different levels in order to better understand the complexity of the entrepreneurial phenomenon. Davidsson et al. (2002) identify the myriad challenges associated with studying the factors associated with the survival, growth and performance of entrepreneurial business ventures, with these factors spread across different levels. To help address some of these concerns, this study investigates both individual and firm specific factors that may affect start-ups' chances of survival and performance. In particular, this paper presents and validates a theoretical model linking individual characteristics of the founding or lead innovative entrepreneur of a start-up venture - the entrepreneur's values, entrepreneurial attitudes and entrepreneurial selfefficacy (ESE) - to the firm's entrepreneurial orientation (EO) and market orientation (MO) and, ultimately, to performance.

In entrepreneurship research, much of the focus has been placed on US Silicon Valley-type contexts and different variants as prime examples of regional entrepreneurial or innovation systems (Saxenian, 1994; Koepp, 2002; Rosenberg, 2002). However, these are relatively unique environments for new ventures when compared to those operating in most other parts of the world (Welter et al., 2017). It is important to understand how fundamental entrepreneurial processes may differ in affecting performance outcomes in non-Silicon Valley contexts. As such, the study focuses on early-stage micro- and small entrepreneurial business ventures in a slow-growing regional Australian economy, South Australia, which has been undergoing economic transformation (Seet et al., 2018).

In recent times, in collaboration with various stakeholders in the regional entrepreneurial ecosystem, the South Australian State Government has initiated programs to transform the South Australian economy, with a special focus on innovation and entrepreneurship, in smallto-medium enterprises (SMEs) (Government of South Australia, 2014). These initiatives took off after the Global Financial Crisis of 2008, with the establishment of technology accelerators, various co-working spaces for start-ups, business incubators such as ThincLab, a Future Industries Institute, the Adelaide Gig City program, and a South Australian Government Research, Commercialisation and Start-up Fund. We recognise that the set of self-employed people is highly heterogeneous in nature. This paper focuses on start-up or lead entrepreneurs who initiate innovative actions in the entrepreneurial process (Schumpeter, 1934; Hébert and Link, 2006; Block et al., 2017). We examine opportunitybased rather than necessity-based entrepreneurs; that is, people who identify an opportunity and take the necessary actions to analyse and exploit the opportunity.

Key elements of entrepreneurship at the firm level include innovativeness, risk-taking, proactiveness, autonomy and competitive aggressiveness (Lumpkin and Dess, 1996, 2001). The attributes of the founding or lead entrepreneurs contribute toward firm-level entrepreneurship and are important to new start-ups and smaller dynamic entrepreneurial business ventures (Miller, 1983; Covin and Slevin, 1991). For example, the values and visions of the founder or lead entrepreneur are a strong component of the culture, values and vision of the firm with there being substantial overlap between the individual orientations of the entrepreneur and the firm (Kropp et al., 2008). Therefore, the processes, methods, styles, practices and decision-making activities of the lead or founding entrepreneur guide the firm (Stevenson and Carlos Jarillo, 1990; Lumpkin and Dess, 1996, 2001).

Entrepreneurship researchers have recognised the interplay between the entrepreneur and the firm and there have been some efforts to study the phenomena (e.g. Canina et al., 2010). However, given the difficulty in translating methodology and constructs that are appropriate at one level of analysis to another, most entrepreneurship research undertaken does not incorporate different levels of analysis in the same study (Davidsson and Wiklund, 2001).

Understanding early-stage firm

performance

261 
IJM

42,2

Indeed, there has been some resistance to dual levels of analysis by entrepreneurship researchers. For example, efforts that attempt to analyse entrepreneurship through different ontologies and epistemologies have led to claims that this inconsistency will affect the legitimacy of the entrepreneurship field (West, 2003). Others have warned that given entrepreneurship research is relatively new, integrating approaches from different fields may lead to increasing contestability within the entrepreneurship field thereby affecting consensus building (Schindehutte and Morris, 2009). This has resulted in the following as noted by Canina et al. (2010):

Over two decades have elapsed since the Low and MacMillan's recommendation (1988:152) and no predominant and clear-cut theoretical paradigm or dominant theory stands out regarding the joint firm and individual level in the entrepreneurship panorama. (p. 273)

Canina et al. (2010) call for this to be addressed because reconciling the different aspects from different fields is a unique source for new paradigms, and it stimulates innovation, which is central to entrepreneurship research.

This research attempts to partially address this gap in the literature by integrating different levels of entrepreneurship research through the examination of individual and firm specific factors that may affect start-up chances of survival and performance. In particular, we test a theoretically based model linking attributes of the founding or lead entrepreneur with specific firm-level factors. The individual-level constructs we examine include the internal dimension of personal values (Kahle, 1983), entrepreneurial attitude (Robinson et al., 1991) and ESE (McCline et al., 2000). The firm-level constructs include three components of EO - proactiveness, risk-taking and innovativeness (Lumpkin and Dess, 1996, 2001), MO and firm performance. The research contributes to the literature by improving our understanding of the heterogeneity within a self-employed group; in particular, among opportunity driven entrepreneurs, with a focus on expanding insights regarding antecedents and consequences of the EO and MO. It examines how some of these factors contribute to the outcomes of entrepreneurs and young firms which, to date, remain under-explored (Acs et al., 2017). It also contributes to the deeper knowledge of the factors affecting entrepreneurial performance in contexts outside the mainstream or "Silicon Valley" type of entrepreneurship by addressing the call to enhance research on contextual entrepreneurship (Welter et al., 2017, 2018).

Using structural equation modelling (SEM), this research develops and tests a theoretically based model linking attributes of the founding or lead entrepreneur with specific firm-level factors. We find that focusing just on individual- or firm-level constructs in isolation provides only a partial insight into the understanding of early-stage venture performance. Examining individual entrepreneur constructs (internal values, entrepreneurial attitude and ESE) as antecedents to key firm-level constructs (entrepreneurial and MO) provides a more holistic understanding of the drivers of firm performance.

\section{Literature review}

Explanations of entrepreneurial performance have to date focused on either the entrepreneur or the firm. We argue that this, unfortunately, may promote a problem of partiality by ignoring the need to understand the interaction of both individual- and firm-level drivers and effects. In the next two sub-sections, we review the individual-level and firm-level factors that are the focus of this research.

\section{The individual level}

Values. Values provide the foundations for our research. Values are higher-order social cognitions that can be viewed as antecedents of attitudes and behaviour. Values shape attitudes which, in turn, shape behaviours (Homer and Kahle, 1988). Rokeach (1973) described 
values as "enduring beliefs that a particular mode of behaviour or end-state of existence is preferable to opposite modes of behaviour or end-state" (p. 5). Personal values are cognitive representations of universal human and social interaction requirements (Schwartz and Bilsky, 1990). They are shaped by life experiences and cultural context and are adaptive as they guide attitudes and behaviours (Kahle, 1983). Values are fundamental to personal identity and cognitive processing styles and vary amongst individuals (Claxton et al., 1996).

Values have been shown to play an important role in shaping attitudes and behaviours. As higher order abstract social cognitions, values represent the ability to adapt and shape adaptive attitudes and behaviours. Values also serve an important role in shaping motivations and decision-making processes. We believe values play an important role in entrepreneurial motivations, attitudes and behaviours. Therefore, we examine values as a precursor to entrepreneurial attitudes, self-efficacy and EO.

Three major approaches dominate the values literature in business: Rokeach (1973), Kahle (1983) and Schwartz and Bilsky (1990). The List of Values (LOV) developed by Kahle (1983) is, perhaps, the most prevalent in the business literature and has been used cross-culturally. It is more parsimonious than the other value structures. LOV is a multidimensional structure that has nine basic values that load on three separate dimensions: internal, external and interpersonal values. Internal values are called internal because they do not require a real or imagined other to validate an individual (Kropp et al., 2005). As previous research indicates that entrepreneurs are internally motivated (Lindsay and Kropp, 2015), our focus in this study is on internal values.

In recent research, it has been found that these domain-specific values positively influence behaviour and usage of social media among so-called digital natives (Brännback et al., 2017). It follows that values may influence entrepreneurial behaviour in rapidly changing contexts. We examine the relationship among values and the other constructs in subsequent sections.

Entrepreneurial attitude. Robinson et al. (1991) developed a multidimensional entrepreneurial attitude orientation (EAO) scale with four dimensions: achievement in business, innovation in business, perceived personal control of business outcomes and perceived self-esteem in business. McCline et al. (2000) acknowledged the importance of Robinson et al. (1991)'s pioneering effort in developing the new entrepreneurial attitude scale; however, they felt that two important components, risk taking and opportunity recognition, were missing from the scale and undertook a refinement effort. Although not successful in capturing the risk-taking component, McCline et al. (2000) developed a new measure for the opportunity recognition component called "entrepreneurial attitude opportunity recognition" (EOR).

Attitudes are most often conceptualised as a tripartite construct with a cognitive component, an affective component and a behavioural intent component (Fishbein, 1963; Fishbein and Ajzen, 1974; Ajzen, 1991). The EOR uses this approach. The cognitive component contains thoughts and beliefs about the entrepreneurial opportunity. The affective or emotional component contains feelings about the opportunity. The behavioural intent or conative component contains the predispositions to behave in a certain way towards the opportunity (McCline et al., 2000).

Attitude measures have been found to be useful particularly in the early stages of the entrepreneurial dynamic (Autio et al., 2018); i.e. the start-up stage, as this is when individuals decide whether or not to engage in entrepreneurial activities. However, entrepreneurial attitudes have also been shown to be important in regulating post-entry entrepreneurial behaviours (e.g. entrepreneurial growth orientations (Autio et al., 2013)) by providing a reflection of informal institutions shaping the regulatory environment and societal resource allocations (Henrekson, 2005). We examine the interrelationships between values, EOR, ESE and $\mathrm{EO}$ in subsequent sections of this paper.

Entrepreneurial self-efficacy. Based on social learning theory, self-efficacy measures an individual's belief that he or she can exercise control in a given situation (Wood and Bandura, 1989). 
IJM

42,2

264

People with high self-efficacy have a high level of confidence in their ability to complete a specific task. This is important because self-efficacy can be predictive of behaviour, i.e. the willingness to attempt a task (Locke et al., 1984; Wood and Bandura, 1989; Bandura, 1991).

ESE is grounded in the context of entrepreneurship and measures the confidence in the willingness to attempt entrepreneurial tasks. Chandler and Jansen (1997) define ESE as the "founder's self-perceived ability to recognise and envision taking advantage of opportunity" (p. 98). Previous research has found ESE to play a role in perceptions of entrepreneurship (Peterman and Kennedy, 2003), differences between entrepreneurs and managers (Chen et al., 1998), the study of entrepreneurship and start-up (Boyd and Vozikis, 1994) and new venture performance (Chandler and Jansen, 1997).

Given the highly dynamic and hence, the relatively stressful nature of high technology entrepreneurship (Uy et al., 2013), Chan et al. (2015) found that entrepreneurs in incubators display coping behaviours that lead to positive interpretations of the experience which should enhance the effect of ESE on outcomes. In this paper, we examine ESE as an individual-level characteristic. We believe that individual ESE motivates individuals to attempt entrepreneurial actions or behaviours and these will impact firm performance; that is, the greater the confidence in taking on entrepreneurial tasks and taking advantage of opportunity, the more likelihood the increase in firm performance.

Interrelations among individual-level constructs. Our research rests on a purposive view of entrepreneurial behaviour and motivation. From this perspective, psychological factors are most readily analysed as a reflection of an individual's fundamental values and beliefs (Casson, 2005).

Homer and Kahle (1988) conducted a pioneering study in values research in the marketing area. Using a structural model, they demonstrate a values-attitudes-behaviour linkage. Values shape attitudes which, in turn, shape behaviour. They found that internal values played a significant role in attitudes towards natural foods that, in turn, resulted in the consumption of more natural food.

In an early-stage venture, the values, attitudes and ESE of the founding or lead entrepreneur are especially important to the firm. In some cases, the founding or lead entrepreneur may be the firm. This is especially true in a start-up or early-stage ventures. In more established firms, the founding or lead entrepreneur will exert a strong influence on the firm to varying degrees.

Previous research identifies that entrepreneurs are internally motivated (Lindsay et al., 2008). These motivations relate to self-concept and include self-respect or self-fulfilment. Therefore, internal values play an important role in shaping attitudes. Since EOR is an attitudinal measure, internal values will shape EOR. Krueger and Carsrud (1993) also identified that entrepreneurial intentions predict entrepreneurial behaviours. Kolvereid and Isaksen (2006) found that perceived behavioural control could be viewed as an antecedent of intentions and behaviours and this could point to a direct positive relationship between EOR and ESE.

\section{The firm level}

Entrepreneurial orientation. Lumpkin and Dess (1996) developed a model that relates EO with firm performance. EO is a firm-level construct that refers to the processes, practices and decision-making activities entrepreneurs use in an entrepreneurial firm (Lumpkin and Dess, 1996). Though conceptualised as a multidimensional construct containing up to five different dimensions, three dimensions have appeared most in the literature: proactiveness, innovativeness and risk-taking (Rauch et al., 2009; Wales et al., 2013). Numerous studies have shown that firms with an EO perform better than those without one (e.g. Kropp et al. (2006)). 
Proactiveness is a forward-looking opportunity-based perspective of introducing new products/services in anticipation of future demand (Knight, 1997; Lumpkin and Dess, 2001).

Risk-taking involves a willingness to take decisive actions such as introducing new products or entering new markets, committing resources in uncertain conditions and borrowing (Lumpkin and Dess, 1996). Although risk-taking can be at the individual level (Brockhaus, 1980; Sitkin and Pablo, 1992), it is a firm-level trait in the context of EO (Baird and Thomas, 1985). Forlani and Mullins (2000) describe entrepreneurial risk as involving uncertainty and the potential of financial loss.

Innovativeness is an important dimension of entrepreneurship (Miller, 1983; Shane and Venkataraman, 2000). Kropp et al. (2006) identify the innovativeness component of EO is positively correlated to the performance of a new business. Innovativeness is important to the development of new products, markets, processes and techniques (Schumpeter, 1934; Miller, 1983). Innovative firms outperform other types of firms (McKee et al., 1989).

Market orientation. MO measures the market focus of the firm. There are multiple definitions of $\mathrm{MO}$; however, there is a commonality among the definitions. Market-oriented firms recognise and respond to changes in consumer needs. They also respond to competitive moves made by other firms in their industry. MO is important to firms because it captures their ability to anticipate, address and capitalise on market changes in customer needs that lead to enhanced performance.

A substantial body of research in MO has established a link between MO and firm performance (Deshpandé et al., 1993; Jaworski and Kohli, 1993; Deshpandé et al., 2000). Market-oriented firms capitalise on these changes leading them to superior performance compared with less market-oriented firms. An MO-Performance relationship has been established for domestic and international firms (e.g. Rose and Shoham, 2002), a link also substantiated in a meta-analysis (Shoham et al., 2005).

Although MO is important to success, there has been limited research into the MO of entrepreneurial business ventures (for two exceptions, see Kara et al., 2005; Kropp et al., 2006). Migliori et al. (2017), in their study of university spin-offs, of which about half were technology spin-offs, found that firm performance and survival depended on the balance between MO and other strategic orientations (e.g. EO).

\section{Linking individual-level and firm-level constructs}

In contrast to the Lumpkin and Dess (1996) model, which examines firms rather than individuals, many entrepreneurship studies examine individual-level constructs, such as an entrepreneur's values, attitudes or confidence in his or her ability to perform the tasks inherent to conducting an entrepreneurial business. It is rare that both the individual-level and firm-level characteristics are studied together, thereby losing the richness that both have to offer. This study is an attempt to bridge this research gap.

The conceptual model underpinning this research is shown in Figure 1. In short, individual values can be expected to drive entrepreneurial attitudes which, in turn, are likely to drive ESE. Both entrepreneurial attitudes and self-efficacy are therefore anticipated to drive the three components of an $\mathrm{EO}$ while entrepreneurial attitudes will be expected to drive $\mathrm{MO}$. In turn, both $\mathrm{EO}$ and $\mathrm{MO}$ are predicted to drive performance.

\section{Methodology \\ Sample and procedures}

The data collection process followed techniques similar to other entrepreneurship and small business researchers in Australia (Romano et al., 2001; Tanewski and Carey, 2007; Graves and Seet, 2017). Approval was obtained from the University's Human Research Ethics 


\section{IJM \\ 42,2}

\section{6}

Figure 1 .

Conceptual model

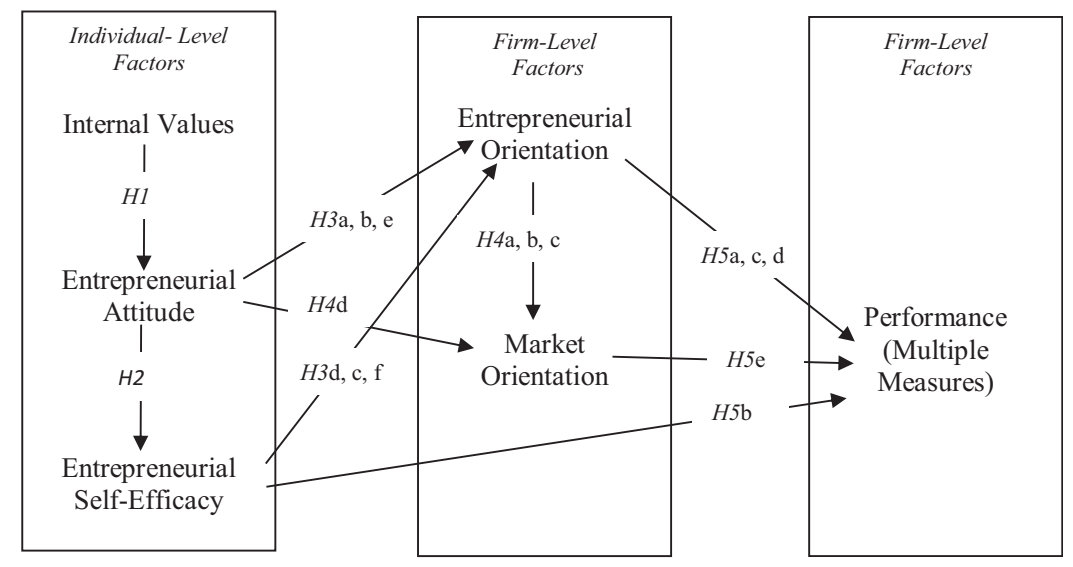

Committee at the start of the data collection phase. The initial version of the survey was pretested among $21 \mathrm{MBA}$ students who had expressed interest in self-employment and/or entrepreneurship and were undertaking an entrepreneurship elective unit. Based on pre-test feedback and the length of the survey, it was converted from an electronic version to a paperbased mail-out version. In order to raise the response rate, $\$ 10$ was donated to the Save the Children Charity for every completed questionnaire received.

For the actual survey, following methods similar to earlier studies in Australia (Carey et al., 2005; Tanewski and Carey, 2007; Carey and Tanewski, 2016), we purchased a stratified random sample of 1,000 founders of early-stage South Australian micro- and small enterprises that were five years or younger in age, from Dun and Bradstreet Australia. The questionnaire was sent to the founder-lead entrepreneur, together with a cover letter that explained the purpose of the study and outlined an incentive to encourage participation (donation made to charity). A follow-up letter was sent three weeks after the initial questionnaire was distributed.

Public sector, mining and non-employing firms were excluded. This is because there were many not-for-profits registered as businesses under public administration and that there were many corporate spin-offs from large mining-sector firms, as is the case in most states in Australia. Many of the non-employing firms were also holding companies. One hundred and thirty surveys were returned as undeliverable. There were 209 questionnaires returned. This resulted in an effective response rate of $24 \%$, which is comparable to other research on SMEs and entrepreneurial ventures conducted in South Australia (e.g. Ahmad et al., 2011; Graves and Seet, 2017; Jones and Corral de Zubielqui, 2017; Corral de Zubielqui et al., 2019). Of the 209 surveys received, 204 were useable $(23 \%)$.

About half the sample respondents run micro-enterprises (those with 1-4 employees as we excluded non-employing firms), with the other half running small firms (those with 5-20 employees) (ABS, 2002). The gender distribution among these early-stage entrepreneurs is predominantly male $(86 \%)$. Also, in line with a largely ageing population in South Australia, which has the highest average age of the mainland States in Australia, two-thirds of the sample are in their late forties or older. About a third or 30\% of the respondents had a university degree or higher. This is consistent with other research and demographic data (ABS, 2002, 2013, 2018). Interestingly, at least one-third of the respondents had started a business before their current venture; i.e. they had previous entrepreneurial experience.

Table 1 compares the industry categories of the 204 survey responses to the Dun and Bradstreet dataset. Both groups are consistent, except for under-representation in the retail 


\begin{tabular}{|c|c|c|c|c|}
\hline Industry & $\begin{array}{c}\text { Dun and Bradstreet } \\
(\%)\end{array}$ & $\begin{array}{l}\text { Study }(n=204) \\
(\%)\end{array}$ & $\begin{array}{c}\text { Difference } \\
(\%)\end{array}$ & $\begin{array}{l}\text { Understanding } \\
\text { early-stage }\end{array}$ \\
\hline Agriculture, forestry and fishing & 3.05 & 8.82 & -5.77 & \\
\hline Construction & 9.17 & 14.71 & -5.53 & performance \\
\hline Finance, insurance and real estate & 4.36 & 5.88 & -1.52 & \\
\hline Manufacturing & 17.24 & 17.16 & 0.08 & \\
\hline Mining & 0.00 & 0.86 & -0.86 & 267 \\
\hline Public administration & 0.00 & 0.49 & -0.49 & \\
\hline Retail trade & 18.35 & 11.27 & 7.07 & \\
\hline Services & 31.96 & 25.49 & 6.47 & \\
\hline $\begin{array}{l}\text { Transportation, communications, electric, gas and } \\
\text { sanitary services }\end{array}$ & 4.51 & 6.37 & -1.87 & \\
\hline Wholesale trade & 11.36 & 8.33 & 3.03 & \\
\hline Total & 100 & 100 & 0 & Comparison of survev \\
\hline \multicolumn{4}{|c|}{$\begin{array}{l}\text { Note(s): Dun and Bradstreet Australia (now known as illion) maintains a database that is a comprehensive } \\
\text { representative registry of privately owned (i.e. unlisted) Australian firms }\end{array}$} & $\begin{array}{l}\text { responses and Dun and } \\
\text { Bradstreet by industry }\end{array}$ \\
\hline
\end{tabular}

and services industries and over-representation in the agriculture, forestry, fishing and construction industries. There could also be some differences of interpretation between the dataset supplier and the founder-owner as evidenced in the self-reported cases in public administration (1) and in mining (4), although these sectors were excluded in the research.

\section{Measures}

The questionnaire contained several sections, some of which were not used in this study. We describe the general structure of the questionnaire and describe the measures for the variables included in this study. The instrument started with questions about the general characteristics of the business; e.g. size, type of business and number of employees. The next section detailed the reasons for starting a business and perception of how successful the respondent was in achieving these reasons. This was followed by a section on personal characteristics and the LOV(detailed below). The following section involved self-reports about viewpoints as a business owner and the business' present condition. The subsequent section included measures of entrepreneurial attitude, EO, ESE and business performance, all detailed below. The final section contained questions about the demographic characteristics of the respondent.

Values. Personal values of the entrepreneur were measured using the nine item List of Values or "LOV" (Kahle, 1983). LOV is a parsimonious construct and demonstrates excellent psychometric properties (Kropp et al., 2005). The instrument has nine items, using a ninepoint Likert-like scale, anchored by $1=$ "Important to Me" and $9=$ "Extremely Important to Me". Although it may seem counter-intuitive at first, the scale is anchored by "important to me," rather than "unimportant" because each of the nine values included in LOV is inherently important otherwise it would not have made the list. If it were labelled as "unimportant", it would eliminate variance between the values as all would be rated as important. Examples of LOV items include "Sense of Belonging (to be accepted needed by friends, family, and community)", "Excitement (to experience stimulation and thrills)" and "Self-Respect (to be proud of myself and confident of who I am)". Self-fulfilment, self-respect and sense of accomplishment are the three internal values in the LOV scheme. The nine items contained in LOV load on three different dimensions: internal values, external values and interpersonal values. Internal values were used in this study. The three values contained in the composite dimension of internal values are self-fulfilment, self-respect and sense of accomplishment. 
IJM

42,2

\section{8}

Entrepreneurial Attitude (EA). EA was measured using the McCline et al. (2000) scale on attitude towards opportunity recognition (EOR). Since opportunity recognition is central to entrepreneurship (Schwartz et al., 2005), we focus on the EOR component in this study. McCline et al. (2000) identified the EOR scale to be more parsimonious in predicting entrepreneurial attitudes and differentiating entrepreneurs from non-entrepreneurs than Robinson et al.'s (1991) scale, although they acknowledge that the EOR scale could be used advantageously in conjunction with Robinson et al.'s (1991) EAO achievement and perceived personal control subscales. For parsimony, this research uses only the EOR scale. The instrument has seven items, using a ten-point Likert-like scale, anchored by one = "Strongly Disagree" and $10=$ "Strongly Agree". Examples of scale questions include: "I like talking to people to find out how I can provide better services." and "I believe I can identify what a customer needs to make them satisfied".

Entrepreneurial Self-Efficacy. We use established ESE measures as developed by Chen et al. (1998) and further enhanced by Zhao et al. (2005). The instrument has four items, using a five-point Likert-like scale, and these items gauge an individual's belief, anchored by "no confidence" to "complete confidence", that he or she could carry out the activities necessary to be a successful entrepreneur. Question examples include "How confident are you in your present readiness for successfully ... identifying new business opportunities? ... commercialising an idea or new development?"

Entrepreneurial Orientation. Although Lumpkin and Dess (1996) conceptualise EO to include autonomy, innovativeness, risk-taking, proactiveness and competitive aggressiveness, not every dimension is universally accepted by others (Covin and Slevin, 1991; Zahra, 1991; Kreiser et al., 2002; Marino et al., 2002). In measuring EO, we use the measures developed by Lumpkin and Dess $(1996,2001)$ to measure the three most widely used dimensions based on a review of the literature as established by Covin and Slevin (1989) - proactiveness, innovativeness and risk-taking. These items are anchored at each end and use a seven-point Likert-type scale. Examples of items from the survey instrument (Lumpkin and Dess, 1996, 2001) (include ... "Innovativeness: In general, the top managers of our firm favour ... (1) A strong emphasis on the marketing of tried and true products and services. ... (7) A strong emphasis on R\&D, technological leadership, and innovation."; "Risk Taking: In general, the top managers of our firm have ... (1) A strong proclivity for low risk projects (with normal and certain rates of return)... (7) A strong proclivity for high risk projects (with chances of very high returns)"; and "Proactiveness: In dealing with its competitors, my firm ... (1) Typically responds to action that competitors initiate. ... (7) Typically initiates actions that competitors then respond to."

Market orientation. Three scales dominate the marketing literature (Kohli and Jaworski, 1990; Narver and Slater, 1990; Deshpandé et al., 1993). Each measures MO and "the three scales appear to be interchangeable" (Deshpandé and Farley, 1998, p. 222). Consequently, for reasons of parsimony, the nine-item Deshpandé et al. (1993) scale was selected, anchored by 1 = "Strongly Disagree" and 5 = "Strongly Agree". Examples of items from this scale include ... "we have routine or regular measures of customer service", "our product and service development is based on good market and customer information", and "we know our competitors well".

Firm performance. To measure firm performance, we used a scale developed by Zou et al. (1998). This scale includes six 5-point items, anchored by $1=$ "Strongly Disagree" and $5=$ "Strongly Agree", to measure statements such as "the firm has generated a high volume of revenue", "our firm has been very successful" and "the firm has achieved rapid growth".

\section{Measurement models}

Table 2 provides the descriptive statistics for the scales. All reliabilities were greater than 0.70 . Since our measurement models were congeneric (rather than parallel), we used 


\begin{tabular}{lccc}
\hline Variable & Coefficient H reliability* & Mean & Standard deviation \\
\hline Internal values & $0.808(0.780)$ & 7.62 & 1.12 \\
Entrepreneurial attitude & $0.832(0.820)$ & 7.74 & 1.27 \\
Entrepreneurial self-efficacy & $0.712(0.701)$ & 4.05 & 0.61 \\
EO - risk taking & $0.781(0.731)$ & 4.56 & 1.10 \\
EO - innovativeness & $0.728(0.720)$ & 3.75 & 0.92 \\
EO - proactiveness & $0.730(0.726)$ & 5.19 & 1.12 \\
MO & $0.781(0.770)$ & 3.89 & 0.55 \\
Firm performance & $0.815(0.784)$ & 3.90 & 0.66
\end{tabular}

Understanding early-stage firm

performance

Note(s): Coefficient H (Hancock and Mueller, 2001) is an appropriate measure of reliability for congeneric the true reliability

Cronbach alpha reliabilities appear in brackets - calculated using SPSS

Table 2.

Measurement model descriptive statistics

Hancock and Mueller's (2001) coefficient $\mathrm{H}$ to measure reliabilities (rather than Cronbach alpha which provides the lower bound estimate of the true reliability). The analyses used to test the measurement properties of our scales and to evaluate the hypotheses are described below. Given the multivariate nature of the model and the need to assess both the measurement properties of the scales and the substantive relationships between them simultaneously, we used SEM (using AMOS V26).

Table 3 presents the fit statistics for the latent variable measurement models. The $\chi^{2}$ statistics for each of the measurement models was not significant indicating there is no significant difference between the sample variance/covariance matrix and the model implied variance/covariance matrix for each model. Hence, the data fits the models well and the models are confirmed. Further fit indices also supported the fit between the sample and the models. For example, in each case, the Goodness of Fit Indices (GFI) and Adjusted Goodness of Fit Indices (AGFI) were greater than 0.950 - values close to 1.00 indicate a close fit (Jöreskog and Sörbom, 1984; Hu and Bentler, 1995); the Root Mean Square Error of Approximation (RMSEA) was less than 0.05, PCLOSE was greater than 0.05 and Lower $90 \%$ confidence interval $<0.05$, which indicate close model fit (Browne and Cudeck, 1993); the Tucker Lewis Index (TLI) (Tucker and Lewis, 1973) was greater than 0.950 (its value can exceed $1.00-\mathrm{Hu}$ and Bentler (1999) recommend a cut-off value of close to 0.950); the Comparative Fit Index (CFI) was greater than 0.950 (Bentler, 1990); and the Standardised Root Mean Square (SRMR) was less than 0.06 (Hu and Bentler, 1998). These indices, all of which are within the recommended cut-off limits, provide additional support to the $\chi^{2}$ statistics that the data fits the measurement models.

Discriminant validity. The two most common approaches for assessing discriminant validity are Fornell and Larcker's (1981) AVE Method and Bagozzi et al's (1991) nested model method. For simplicity, we used the nested model method developed by Bagozzi et al. (1991) to test for discriminant validity. In essence, if the correlation between two constructs is 1.00, then we must conclude that the two constructs are one construct rather than two. Bagozzi et al.'s (1991) approach to discriminant validity is to first run the model unconstrained and note the Chi Square, and then constrain the correlation between the constructs to 1.00 and again, note the Chi Square. If a difference Chi Square test shows that constraining the correlation between the two constructs does not significantly worsen the model fit, then we fail to conclude that the constructs differ. In this research, in all cases, constraining the correlation between the constructs to 1.00 significantly worsens the model; thus, we can conclude that the constructs are different (i.e. discriminant validity holds).

Common method bias. We examined common method bias (CMB) using a latent factor approach (Podsakoff et al., 2003, 2012). This involved comparing the standardised regression 
IJM
42,2

270

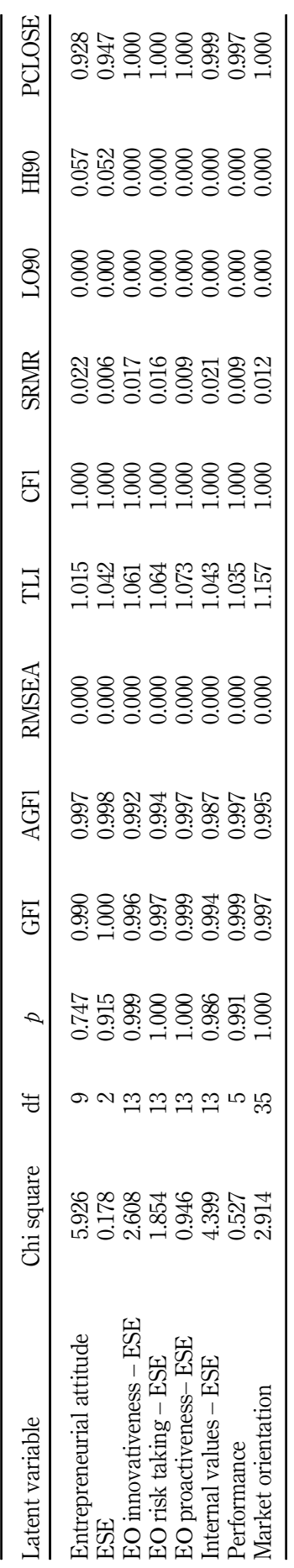

Table 3.

Measurement model model fit statistics 
weights where a common latent factor was used with the standardised regression weights where a common latent factor was not used and the differences (delta) examined. Using a cutoff of 0.1 for $\mathrm{CMB}$, there were no delta results greater than 0.1 . As such, we conclude that it is unlikely that CMB exists. We did also initially use the simplistic Harman's one factor test which also suggested no evidence of $\mathrm{CMB}$.

Late response bias. Late response bias was also considered. We examined the size of business (number of employees), nature of business (industry type) and business location for those responses that we received within the first week against those received subsequently. We identified no apparent differences across time in the responses received. All responses were received within four weeks of the initial mailout with one reminder letter sent two weeks after the initial mailout.

\section{Structural model}

The $\chi^{2}$ statistic for the structural model was not significant and other model fit statistics, which are within the recommended cut-off limits, indicate the data fits the model well (e.g. $\mathrm{GFI}=0.996$; $\mathrm{AGFI}=0.987$;MSEA $=0.000, \mathrm{PCLOSE}=0.999$, and Lower $90 \%$ confidence interval $=0.000$; TLI $=1.059 ; \mathrm{CFI}=1.000$ (Bentler, 1990); and SRMR $=0.015$ ). Thus, the model is confirmed. Table 4 provides the correlation matrix.

\section{Results}

\section{Test of hypotheses}

Given that the data set fits the model, the following observations can be made about the results with the standardised regression weights, squared correlation $\left(R^{2}\right)$ details and relevant hypotheses appearing in Figure 2 structural model. The $R^{2}$ for the following dependent variables was as follows: Entrepreneurial Attitude $=0.35 ; \mathrm{ESE}=0.50$; $\mathrm{EO}$ Risk Taking $=0.29$; EO Innovativeness $=0.40 ;$ EO Proactiveness $=0.27, \mathrm{MO}=0.25$ and Firm Performance $=0.53$.

In terms of performance, the ultimate dependent variable (measured using five statement items), it is worth noting the percentage of respondents that "Strongly Agreed" or "Agreed" (compared with those who "Disagreed") with those five items. These items were that, over the past year, a respondent's firm had: Generated a high level of revenue (4\% Strongly Agreed/ Agreed c.f. $29 \%$ who Disagreed); Achieved rapid growth (10\% Strongly Agreed/Agreed c.f. $23 \%$ who Disagreed); Achieved very satisfactory performance (7\% Strongly Agreed/Agreed c.f. $30 \%$ who Disagreed); Been very successful (4\% Strongly Agreed/Agreed c.f. $28 \%$ who Disagreed), and Met the team's financial expectations (11\% Strongly Agreed/Agreed c.f. $24 \%$ who Disagreed). Thus, most of the participants did not believe that their firms had been performing at their peak over the previous 12 months.

All construct inter-relationships were significant except for Entrepreneurial Attitude-EO Risk $(\beta=0.08)$, Entrepreneurial Attitude - EO Proactiveness $(\beta=0.09)$, EO Innovativeness MO $(\beta=0.16)$, EO Risk Taking - MO $(\beta=-0.17)$, EO Proactiveness - Performance $(\beta=0.10)$, and EO Risk Taking - Performance $(\beta=-0.15)$.

Control variables. We controlled for gender, age and education in subsequent analyses. We found that when these variables were introduced into the structural model as control variables, there were no changes to the significance of the model relationships. However, there was a significant positive effect between entrepreneur gender and ESE. Because only $14 \%$ of the entrepreneurs were women, the "cell size" was too small to be definitive about the implications of this result though male entrepreneurs demonstrated a higher entrepreneurial self-efficacy (Mean $=4.08$ ) than female entrepreneurs (Mean $=3.84$ ) - but the difference was not significant. Further research needs to be undertaken in this regard when female entrepreneurs have a greater sample representation. 
IJM
42,2

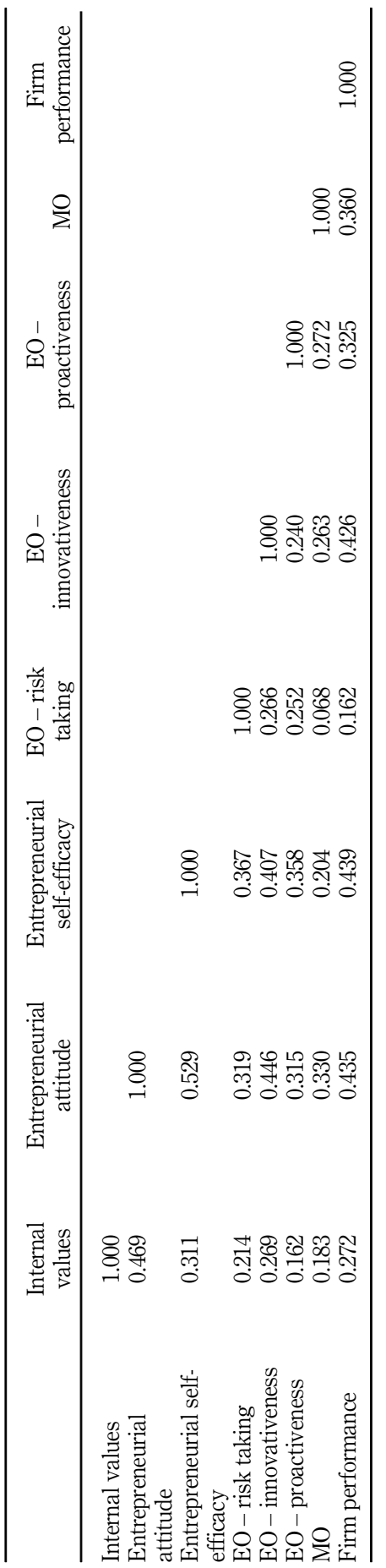

Table 4.
Correlation matrix 


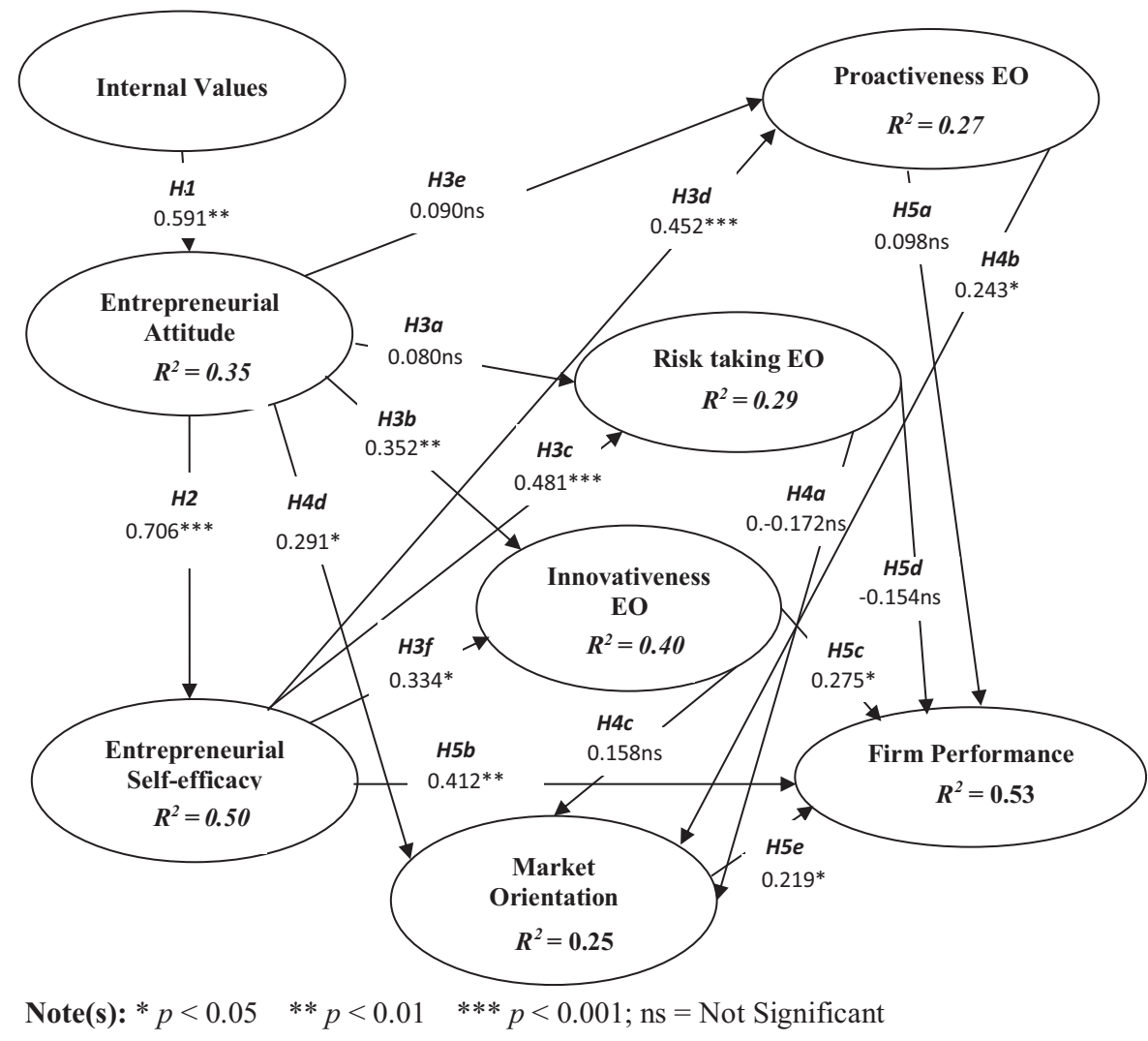

Understanding early-stage firm performance

273

Figure 2. Structural model with hypotheses

We also found a significant negative effect between entrepreneur age and firm performance: the younger the entrepreneur, the higher the firm performance and vice versa.

\section{Discussion, conclusions, implications, limitations and further research}

Contributions to theory

This study examined the inter-relationships among key constructs: values, entrepreneurial attitude and ESE (individual-level constructs) as antecedents to EO, MO and performance (firm-level constructs). In so doing, the study contributes to an understanding of the heterogeneity within self-employed individuals; in particular, among innovative entrepreneurs, with a focus on expanding our awareness of the antecedents and consequences of the entrepreneurial process. It provides insights into the factors affecting self-employment and entrepreneurial performance in contexts outside "conventional" or "Silicon Valley-type" high-technology entrepreneurship. It is also consistent with the call to increase research into the diverse contexts of entrepreneurship (Welter et al., 2017, 2018). In this research, we examine early-stage ventures operating in the context of a regional entrepreneurial ecosystem that is making a significant economic transformation based upon innovation.

Firms with entrepreneurial or MOs obtain superior financial performance and survival rates. Although these orientations are acknowledged as being important, with few exceptions 
IJM

42,2

(e.g. Kropp et al., 2006, 2008), they have generally been studied as separate constructs (Steffens et al., 2006). This study contributes to the literature by examining the two orientations (EO and $\mathrm{MO}$ ) and their effect on performance in a mature developed economy context. In addition, the study also makes a contribution in that there is a lack of research into the antecedents of these orientations (Zahra et al., 1999). This study examines a conceptual model that links firm orientations with individual-level antecedents to determine their combined effects on firm level performance as depicted in the theoretical framework earlier. Although the investigation of integrated individual and organisational level relationships are more common in other management fields (e.g. Trompenaars and Hampden-Turner, 1998), there is a dearth of these studies in entrepreneurship.

Our motivation for this research is that self-employed individuals, specifically innovative entrepreneurs, have a significant impact on the firms they found - particularly in the formative stages of developing their businesses. Thus, looking at either the individual entrepreneur or the firm "in isolation" (without considering constructs at the other level), when a firm is in its formative stages, may be inadequate in explaining firm performance. We find that examining individual entrepreneur constructs (values, entrepreneurial attitude and ESE) as antecedents to key firm-level constructs (entrepreneurial and MO) provide a more holistic understanding of the drivers of firm performance.

In terms of how individual- and firm-level constructs are inter-related in this research, we provide the following observations. Internal values are an antecedent of entrepreneurial attitude which is consistent with theory. Values are more stable than attitudes; therefore, values may be a better predictor of individual entrepreneurship than entrepreneurial attitude.

Entrepreneurial attitude is an antecedent of, and has a significant effect upon, ESE. In turn, ESE is related to EO-Risk Taking, EO-Innovativeness and EO-Proactiveness, and is directly related to firm performance. We note in a post hoc analysis that both values and entrepreneurial attitude have significant positive indirect effects on firm performance.

In addition, entrepreneurial attitude is an antecedent of and has a significant effect upon Marketing Orientation (MO) with MO having a positive direct relationship with firm performance.

Entrepreneurial attitude is not related to either EO-Risk-taking or EO-Proactiveness, but it is a driver of EO-Innovativeness. When Entrepreneurial Attitude is taken out of the model, EO-Innovativeness still remains related to firm performance; thus, EO-Innovativeness is a key antecedent of firm performance in its own right.

Thus, in summary, at the individual level of analysis, values have a positive effect on entrepreneurial attitude which has a direct effect on ESE and EO-Innovativeness. ESE has a direct effect on all three EO constructs, as well as firm performance. Values and entrepreneurial attitude both have indirect effects on firm performance. Entrepreneurial attitude also has a direct relationship with $\mathrm{MO}$ which, in turn, has a direct relationship with firm performance.

Prior research has not investigated either entrepreneurial attitude or ESE as antecedents of EO. We therefore provide insights into the underlying influences of how EO strategies are developed. The more entrepreneurially confident the entrepreneur becomes, the greater the effect this confidence has on developing the $\mathrm{EO}$ of the firm. In addition, prior research has not examined the entrepreneurial attitude-MO relationship and thus we also provide insights into what contributes toward the development of an MO.

Looking at how the different constructs affect performance in detail, $53 \%$ of the variance of firm performance was explained by including both the individual- and firm-level constructs in the structural model. A post hoc analysis revealed that when the individual variables (internal values, entrepreneurial attitude and ESE) were removed, the firm-level variables (EO risk taking, EO innovativeness, EO proactiveness and MO) explained $41 \%$ of firm performance. When the firm variables were removed, the individual level variables 
explained $39 \%$ of firm performance. Thus, both individual- and firm-level variables contribute to firm performance but, when both are included in the model, an additional 12 $14 \%$ of firm performance is explained, which is a significant difference. Thus, greater insights into what contributes to firm performance are gained by including both individualand firm-level variables.

This suggests that for early-stage ventures, the individual-level factors that entrepreneurs bring to a venture are just as important in explaining new venture performance as firm-level factors and supports research that has explored the development of an individual-level EO construct (Bolton and Lane, 2012). Including individual-level factors result in greater insights into the individual entrepreneur's contributions towards firm performance and an improved, richer, understanding of why some firms outperform others.

The results support research in self-employment and entrepreneurship that finds better explanatory power in terms of multilevel approaches, especially at the individual/firm level (Brush et al., 2008). At the same time, we caution against claims that research focusing on the individual is no longer relevant and that entrepreneurship has been "accepted as a team sport or a social game rather than the realm of lone wolves conquering the world on their own" (Davidsson, 2016, p. 20). Instead, this study lends weight to those entrepreneurship researchers who have tried to re-focus and re-discover the individual in their research through investigating behavioural and cognitive issues rather than personality characteristics (Davidsson et al., 2001; Ucbasaran et al., 2001).

\section{Implications for practice}

As economies around the world look toward self-employment/entrepreneurship and innovation as a means for escaping slow growth and delayed development (Singer et al., 2015), this research provides insights for early-stage ventures that could increase the probability of survival and enhanced firm performance, especially that involves innovation. In addition, it provides strategic insights for the development of government policies that are designed to foster innovation, promote enhanced performance and encourage small business formation, longevity and support as they transition through the early stages where survival is difficult.

In particular, this research helps policymakers further understand the links between individual- and firm-level factors in the context of a slow-growth regional economy in its process of radically transforming its economy from one based on manufacturing to one based on innovation. The study's finding that among small early-stage ventures, both individuallevel and firm-level factors contribute towards explaining firm performance has already influenced recent policy changes by the South Australian government. It has wound down early-stage seed funding for technology industries and focused its efforts more on entrepreneurial ecosystem development through supporting networking and start-up events, co-working spaces, incubators and accelerators (Bliemel et al., 2016), which are designed to have effects at both the individual entrepreneur and firm levels. As an example of the effectiveness of the new policies, start-up accelerators focus on nurturing entrepreneurial talent by influencing entrepreneurial behaviour, entrepreneurial tendency and entrepreneurial outcomes largely through mentoring and entrepreneurship education (Matlay, 2008; Seet et al., 2018). In addition to learning from peers, start-up accelerators also offer early-stage entrepreneurs networking opportunities with successful entrepreneurs, early-stage investors and corporate executives (Miller and Bound, 2011; Cohen, 2013), the outcomes of which can have positives effects on firm performance.

Another practical implication is that of potential funders and investors looking beyond just screening business plans in terms of evaluating start-up potential. This is the basis for a new wave of Search Fund Accelerators (SFAs) that support professionals who are highly 
IJM

42,2

\section{6}

motivated would-be entrepreneurs seeking to acquire businesses to run as CEOs (Alemany and Andreoli, 2018). Beside business planning, the SFAs conduct evaluations on both the would-be entrepreneur and the firm using a variety of psychometric and individual level tests and firm level due diligence tools as part of an entrepreneurship-through-acquisition process (Dennis and Laseca, 2016). These are early days for SFAs in smaller developed economies like Australia (Järvinen, 2019). However, guided by a pool of active and professional investors, the SFA model claims to avoid the excesses of the dot-com boom and the buy-out bubble before the Global Financial Crisis of the late 2000s by delivering more successful outcomes for all the stakeholders involved (Wasserstein, 2017). Investors will gain higher returns on their investments, former owners will see their companies better-off and expanded and searchers will become successful CEOs with commensurate personal and financial rewards (Scarato, 2018).

Finally, related to the previous point, there are practical implications of our research for entrepreneurship and self-employment, as the measures used in the research may be helpful in identifying the suitability of opportunity-based entrepreneurship for individuals (Shane, 2003). This is especially helpful before individuals make decisions to be self-employed/entrepreneurs as not all of them may be suited for self-employment/entrepreneurship (Casson, 2005).

\section{Limitations and future directions}

There were several limitations associated with the research. First, the sample was taken from South Australia and across a number of industry sectors. The cell sizes of the various industry sectors were too small to undertake separate SEM analyses. Future research should engage in a national sample with more detailed industry sector analyses undertaken. In addition, it would be interesting to study other countries to identify if these relationships extend cross-culturally.

In addition, there were limitations on the use of the Dun and Bradstreet database. The Dun and Bradstreet database could not distinguish sole traders from those with 1-5 employees. Also, the gig economy has been growing in the category of micro-businesses in terms of Australian data (AiGroup, 2016), even though the concept of gig workers being self-employed contractors or some form of employee has yet to be agreed upon among researchers and regulators (Healy et al., 2017; Todolí-Signes, 2017). Future research should investigate microbusinesses separately from sole traders as well as differentiate between those engaged with the gig economy. The treatment of sole-traders as a separate group is in line with research that shows that sole-traders distort the nature of firm behaviour given their large numbers in Australia (e.g. Parliamentary Joint Committee on Corporations and Financial Services, 2013).

Second, this research is cross-sectional. Future research would benefit from using a repeated-measures, longitudinal growth model with at least three (ideally four) measurement points over time to examine the dynamic nature of the constructs of interest and their interrelationships.

Third, in this study, we used only internal values, entrepreneurial attitude and ESE as the individual-level constructs. Future research should incorporate more recent developments at the individual level such as entrepreneurial human capital (Unger et al., 2011; Gruber et al., 2012), entrepreneurial cognition (Grégoire et al., 2011), the role of emotions (Cardon et al., 2012; Welpe et al., 2012) and patterns of entrepreneurial behaviour such as bricolage (Baker and Nelson, 2005) and effectuation (Sarasvathy, 2001). We also used EO and MO as the firm-level constructs and these could be expanded to include recent developments that locate the firm in the wider inter-organisational context similar to social capital (Gedajlovic et al., 2013) and networking (Newbert et al., 2013).

Fourth, although we used firm-level measures, the study is not a real "multilevel" study in which firm characteristics are measured by aggregating individual-level responses from 
multiple respondents from the same firm (or by using structural indicators of performance). In this research, the same respondent answers the firm and individual level questions. Although there have been calls for more multilevel research in entrepreneurship for the last decade (Shepherd, 2011; Forson et al., 2014), actual empirical studies have proven to be very rare, with most attempting to do so by merged individual and institutional level datasets (e.g. Boudreaux et al., 2019).

Fifth, in terms of understanding individual factors, we acknowledge that entrepreneurs have different starting points to entrepreneurship and are heterogeneous. We did not consider aspects of economic and demographic variables. Even among psychological factors, our research has only looked at those that are tied to values or entrepreneurial attitude. For example, we have not looked at other factors that have been identified in the research such as achievement, challenge and learning, income security and financial success, recognition and status, family and roles, dissatisfaction and community and social motivations (Stephan et al., 2015). We have also not explored factors among individuals undertaking necessity entrepreneurship who, for some reason, have been "pushed" into entrepreneurship and not out of personal choice, especially among those who are self-employed (van der Zwan et al., 2016). These would include factors such as dissatisfaction, low educational level, social marginalisation and socio-economic environment (Munoz, 2010). Also, as our research focuses on the purposive view of entrepreneurial motivation and behaviour, it may not apply to all entrepreneurs. In addition, the sample may be selective, as it only surveys firms (and entrepreneurs) that "survive" and thus is, to a certain extent, inclusive of only those that are relatively more successful.

\section{Summary}

The study contributes to the special issue's aim of improving the understanding of the heterogeneity among the self-employed, in particular among innovative entrepreneurs, with a focus on expanding insights regarding antecedents and consequences of the entrepreneurial process. This is achieved through providing insights into the underlying driving forces of success in early-stage entrepreneurial ventures. Failed businesses, often firms without an EO, result in a loss of income, loss of jobs and an over-all negative impact on national economies and the well-being of society. Overall, the research helps in furthering our knowledge of the extent to which antecedent factors, previously identified in the start-up/self-employment literature, are relevant to firm level outcomes in the context of a regional economy undergoing significant transformation.

Despite its limitations, we feel that this study is innovative because it links the individual values of the lead self-employed individual or founding entrepreneur with firm-level latent variables (EO and $\mathrm{MO}$ ) to performance. In early-stage ventures, individual characteristics of the founding or lead entrepreneurs including their values, attitudes and self-efficacy significantly affect firm behaviour. As Davidsson (2004) notes, "research should pay attention to antecedents and outcomes ..." (p. 61).

In terms of developing policies to support the transformation of traditional economies to ones based on innovation, failing to come to terms with this dynamic will mean that the existing potential for agility and innovation, especially in new ventures, is unlikely to be realised (Roos and O'Connor, 2015).

\section{References}

ABS (2002), Small Business in Australia 2001, Australian Bureau of Statistics, Canberra.

ABS (2013), Australian Social Trends 2013, Australian Bureau of Statistics, Canberra.

ABS (2018), The Labour Force, Australia, Australian Bureau of Statistics, Canberra. 
IJM

42,2

Acs, Z.J., Stam, E., Audretsch, D.B. and O'Connor, A. (2017), "The lineages of the entrepreneurial ecosystem approach”, Small Business Economics, Vol. 49 No. 1, pp. 1-10.

Ahmad, N.H., Wilson, C. and Kummerow, L. (2011), "A cross-cultural insight into the competency-mix of SME entrepreneurs in Australia and Malaysia”, International Journal of Business and Management Science, Vol. 4 No. 1, pp. 33-50.

AiGroup (2016), The Emergence of the Gig Economy, Melbourne.

Ajzen, I. (1991), "The theory of planned behavior", Organizational Behavior and Human Decision Processes, Vol. 50 No. 2, pp. 179-211.

Alemany, L. and Andreoli, J.J. (2018), Entrepreneurial Finance: The Art and Science of Growing Ventures, Cambridge University Press, Cambridge.

Autio, E., Pathak, S. and Wennberg, K. (2013), "Consequences of cultural practices for entrepreneurial behaviors", Journal of International Business Studies, Vol. 44 No. 4, pp. 334-362.

Autio, E., Szerb, L., Komlósi, E. and Tiszberger, M. (2018), The European Index of Digital Entrepreneurship Systems, EUR 29309 EN, Publications Office of the European Union, Luxembourg, ISBN 978-92-79-91303-7, doi: 10.2760/39256, JRC112439.

Bagozzi, R.P., Yi, Y. and Phillips, L.W. (1991), "Assessing construct validity in organizational research", Administrative Science Quarterly, Vol. 36 No. 3, pp. 421-458.

Baird, I.S. and Thomas, H. (1985), "Toward a contingency model of strategic risk taking”, Academy of Management Review, Vol. 10 No. 2, pp. 230-243.

Baker, T. and Nelson, R.E. (2005), "Creating something from nothing: resource construction through entrepreneurial bricolage”, Administrative Science Quarterly, Vol. 50 No. 3, pp. 329-366.

Bandura, A. (1991), "Social cognitive theory of self-regulation", Organizational Behavior and Human Decision Processes, Vol. 50 No. 2, pp. 248-287.

Bentler, P.M. (1990), “Comparative fit indexes in structural models", Psychological Bulletin, Vol. 107 No. 2, pp. 238-246.

Bliemel, M.J., Flores, R.G., de Klerk, S., Miles, M.P., Costa, B. and Monteiro, P. (2016), "The role and performance of accelerators in the Australian startup ecosystem", UNSW Business School Research Paper No. 2016MGMT03.

Block, J.H., Fisch, C.O. and van Praag, M. (2017), "The Schumpeterian entrepreneur: a review of the empirical evidence on the antecedents, behaviour and consequences of innovative entrepreneurship", Industry and Innovation, Vol. 24 No. 1, pp. 61-95.

Bolton, D.L. and Lane, M.D. (2012), "Individual entrepreneurial orientation: development of a measurement instrument”, Education and Training, Vol. 54 Nos 2-3, pp. 219-233.

Boudreaux, C.J., Nikolaev, B.N. and Klein, P. (2019), "Socio-cognitive traits and entrepreneurship: the moderating role of economic institutions", Journal of Business Venturing, Vol. 34 No. 1, pp. 178-196.

Boyd, N.G. and Vozikis, G.S. (1994), "The influence of self-efficacy on the development of entrepreneurial intentions and actions", Entrepreneurship: Theory and Practice, Vol. 18 No. 4, pp. 63-77.

Brännback, M., Nikou, S. and Bouwman, H. (2017), "Value systems and intentions to interact in social media: the digital natives", Telematics and Informatics, Vol. 34 No. 4, pp. 365-381.

Brockhaus, R.H. (1980), "Risk taking propensity of entrepreneurs", Academy of Management Journal, Vol. 23 No. 3, pp. 509-520.

Browne, M.W. and Cudeck, R. (1993), "Alternative ways of assessing model fit. Testing structural equation models", in Bollen, K.A. and Long, J.S. (Eds), Testing Structural Equation models, Sage, Newbury Park, CA, pp. 136-162.

Brush, C.G., Manolova, T.S. and Edelman, L.F. (2008), "Separated by a common language? Entrepreneurship research across the Atlantic", Entrepreneurship Theory and Practice, Vol. 32 No. 2, pp. 249-266. 
Canina, L., Palacios, D. and Devece, C. (2010), "Management theories linking individual and organizational level analysis in entrepreneurship research", The International Entrepreneurship and Management Journal, Vol. 8 No. 3, pp. 271-284.

Cardon, M.S., Foo, M.-D., Shepherd, D. and Wiklund, J. (2012), "Exploring the heart: entrepreneurial emotion is a hot topic", Entrepreneurship Theory and Practice, Vol. 36 No. 1, pp. 1-10.

Understanding early-stage firm

performance

Carey, P. and Tanewski, G. (2016), "The provision of business advice to SMEs by external accountants", Managerial Auditing Journal, Vol. 31 No. 3, pp. 290-313.

Carey, P., Simnett, R. and Tanewski, G. (2005), "Providing business advice for small to medium enterprises”, CPA Australia Business Management Reports, CPA Australia, Melbourne.

Casson, M. (2005), "The individual - opportunity nexus: a review of Scott Shane: a general theory of entrepreneurship", Small Business Economics, Vol. 24 No. 5, pp. 423-430.

Chan, E., Sun, S. and Saleh, S. (2015), "Self-Regulation, learning and advancement: effects of entrepreneurial self-efficacy and coping behaviors on learning and venture goal progress", Frontiers of Entrepreneurship Research, Vol. 35 No. 4, p. 13.

Chandler, G.N. and Jansen, E. (1997), "Founder self-efficacy and venture performance: a longitudinal study", Academy of Management Proceedings, Vol. 1997 No. 1, pp. 98-102.

Chen, C.C., Greene, P.G. and Crick, A. (1998), "Does entrepreneurial self-efficacy distinguish entrepreneurs from managers?”, Journal of Business Venturing, Vol. 13 No. 4, pp. 295-316.

Claxton, R.P., McIntyre, R.P., Clow, K.E. and Zemanek, J.E. (1996), "Cognitive style as a potential antecedent to values", Journal of Social Behavior and Personality, Vol. 11 No. 2, p. 355.

Cohen, S. (2013), "What do accelerators do? Insights from incubators and angels", Innovations: Technology, Governance, Globalization, Vol. 8 Nos 3-4, pp. 19-25.

Corral de Zubielqui, G., Lindsay, N., Lindsay, W. and Jones, J. (2019), "Knowledge quality, innovation and firm performance: a study of knowledge transfer in SMEs", Small Business Economics, Vol. 53 No. 1, pp. 145-164.

Covin, J. and Slevin, D. (1989), "Strategic management of small firms in hostile and benign environments", Strategic Management Journal, Vol. 10 No. 1, pp. 75-87.

Covin, J.G. and Slevin, D.P. (1991), "A conceptual model of entrepreneurship as firm behavior", Entrepreneurship: Theory and Practice, Vol. 16 No. 1, p. 7.

Davidsson, P. (2004), Researching Entrepreneurship, Springer, New York, NY.

Davidsson, P. (2016), "The field of entrepreneurship research: some significant developments", in Bögenhold, D., Bonnet, J., Dejardin, M. and Garcia Pérez de Lema, D. (Eds), Contemporary Entrepreneurship: Multidisciplinary Perspectives on Innovation and Growth, Springer International Publishing, Cham, pp. 17-28.

Davidsson, P. and Wiklund, J. (2001), "Levels of analysis in entrepreneurship research: current research practice and suggestions for the future", Entrepreneurship: Theory and Practice, Vol. 25 No. 4, pp. 81-99.

Davidsson, P., Low, M.B. and Wright, M. (2001), "Editor's introduction: low and MacMillan ten years on: achievements and future directions for entrepreneurship research", Entrepreneurship: Theory and Practice, Vol. 25 No. 4, pp. 5-15.

Davidsson, P., Delmar, F. and Wiklund, J. (2002), "Entrepreneurship as growth: growth as entrepreneurship", in Hitt, M.A., Ireland, R.D., Camp, S.M. and Sexton, D.L. (Eds), Strategic Entrepreneurship: Creating a New Mindset, Blackwell, Oxford, pp. 328-342.

Dennis, J. and Laseca, E. (2016), The Evolution of Entrepreneurship through Acquisition, University of Chicago Booth School of Business, Chicago, IL.

Deshpandé, R. and Farley, J.U. (1998), "Measuring market orientation: generalization and synthesis", Journal of Market-Focused Management, Vol. 2 No. 3, pp. 213-232. 
IJM

42,2

Deshpandé, R., Farley, J.U. and Webster, F.E. (1993), "Corporate culture, customer orientation, and innovativeness in Japanese firms: a quadrant analysis", Journal of Marketing, Vol. 57 No. 1, pp. 23-37, doi: 10.1177/002224299305700102.

Deshpandé, R., Farley, J.U. and Webster, F.E. (2000), "Triad lessons: generalizing results on high performance firms in five business-to-business markets", International Journal of Research in Marketing, Vol. 17 No. 4, pp. 353-362.

Fishbein, M. (1963), "An investigation of the relationship between beliefs about an object and the attitude toward that object", Human Relations, Vol. 16 No. 3, pp. 233-239.

Fishbein, M. and Ajzen, I. (1974), "Attitudes towards objects as predictors of single and multiple behavioral criteria”, Psychological Review, Vol. 81 No. 1, pp. 59-74.

Forlani, D. and Mullins, J.W. (2000), "Perceived risks and choices in entrepreneurs' new venture decisions", Journal of Business Venturing, Vol. 15 No. 4, pp. 305-322.

Fornell, C. and Larcker, D.F. (1981), "Evaluating structural equation models with unobservable variables and measurement error", Journal of Marketing Research, Vol. 18 No. 1, pp. 39-50.

Forson, C., Özbilgin, M., Ozturk, M.B. and Tatli, A. (2014), "Multi-level approaches to entrepreneurship and small business research-transcending dichotomies with Bourdieu”, in Chell, E. and KarataşÖzkan, M. (Eds), Handbook of Research on Small Business and Entrepreneurship, Edward Elgar Publishing, Cheltenham, pp. 70-82.

Gedajlovic, E., Honig, B., Moore, C.B., Payne, G.T. and Wright, M. (2013), "Social capital and entrepreneurship: a schema and research agenda", Entrepreneurship Theory and Practice, Vol. 37 No. 3, pp. 455-478.

Government of South Australia (2014), Vision SA: The Place where People and Business Thrive, Economic Development Board SA, Adelaide.

Graves, C.R. and Seet, P.S. (2017), "Internationalization through investor, advisory board, and accountant networks: an exploratory study of Australian SMEs", in Thirawat, N. (Ed.), Internationalization and Managing Networks in the Asia Pacific, Elsevier and Chandos Publishing, Cambridge, MA, pp. 143-168.

Grégoire, D.A., Corbett, A.C. and McMullen, J.S. (2011), "The cognitive perspective in entrepreneurship: an agenda for future research", Journal of Management Studies, Vol. 48 No. 6, pp. 1443-1477.

Gruber, M., MacMillan, I.C. and Thompson, J.D. (2012), "Escaping the prior knowledge corridor: what shapes the number and variety of market opportunities identified before market entry of technology start-ups?”, Organization Science, Vol. 24 No. 1, pp. 280-300.

Hancock, G.R. and Mueller, R.O. (2001), "Rethinking construct reliability within latent variable systems", in Cudeck, R., Du Toit, S. and Sörbom, D. (Eds), Structural Equation modeling: Present and Future, Scientific Software International, Chicago, pp. 195-216.

Healy, J., Nicholson, D. and Pekarek, A. (2017), "Should we take the gig economy seriously?", Labour and Industry: A Journal of the Social and Economic Relations of Work, Vol. 27 No. 3, pp. 232-248.

Hébert, R.F. and Link, A.N. (2006), "The entrepreneur as innovator", The Journal of Technology Transfer, Vol. 31 No. 5, pp. 589-597.

Henrekson, M. (2005), "Entrepreneurship: a weak link in the welfare state?", Industrial and Corporate Change, Vol. 14 No. 3, pp. 437-467.

Homer, P.M. and Kahle, L.R. (1988), "A structural equation test of the value-attitude-behavior hierarchy”, Journal of Personality and Social Psychology, Vol. 54 No. 4, pp. 638-646.

Hu, L. and Bentler, P. (1995), "Evaluating model fit", in Hoyle, R.H. (Ed.), Structural Equation Modelling, Sage Publications, Thousand Oaks, CA, pp. 76-99.

Hu, L.T. and Bentler, P.M. (1998), "Fit indices in covariance structure modeling: sensitivity to underparameterized model misspecification”, Psychological Methods, Vol. 3 No. 4, pp. 424-453. 
Hu, L.T. and Bentler, P.M. (1999), "Cutoff criteria for fit indexes in covariance structure analysis: conventional criteria versus new alternatives", Structural Equation Modeling: A Multidisciplinary Journal, Vol. 6 No. 1, pp. 1-55.

Järvinen, M. (2019), The Finnish Search Fund Model: A Feasibility Study of the Search Fund Model for the Finnish Market, Aalto University, Espoo, Finland.

Understanding early-stage firm

performance

Jaworski, B.J. and Kohli, A.K. (1993), "Market orientation: antecedents and consequences", Journal of Marketing, Vol. 57 No. 3, pp. 53-70.

Jones, J. and Corral de Zubielqui, G. (2017), "Doing well by doing good: a study of university-industry interactions, innovationess and firm performance in sustainability-oriented Australian SMEs", Technological Forecasting and Social Change, Vol. 123, pp. 262-270.

Jöreskog, K.G. and Sörbom, D. (1984), LISREL VI: Analysis of Linear Structural Relationships by Maximum Likelihood, Instrumental Variables, and Least Squares Methods, Scientific Software, Mooresville.

Kahle, L.R. (1983), Social Values and Social Change: Adaptation to Life in America, Praeger Publishers, New York, NY.

Kara, A., Spillan, J.E. and DeShields, O.W. (2005), "The effect of a market orientation on business performance: a study of small-sized service retailers using MARKOR scale”, Journal of Small Business Management, Vol. 43 No. 2, pp. 105-118.

Knight, G.A. (1997), "Cross-cultural reliability and validity of a scale to measure firm entrepreneurial orientation", Journal of Business Venturing, Vol. 12 No. 3, pp. 213-225.

Koepp, R. (2002), Clusters of Creativity: Enduring Lessons on Innovation and Entrepreneurship from Silicon Valley and Europe's Silicon Fen, John Wiley, Chichester.

Kohli, A.K. and Jaworski, B.J. (1990), "Market orientation: the construct, research propositions, and managerial implications", Journal of Marketing, Vol. 54 No. 2, pp. 1-18.

Kolvereid, L. and Isaksen, E. (2006), "New business start-up and subsequent entry into selfemployment”, Journal of Business Venturing, Vol. 21 No. 6, pp. 866-885.

Kreiser, P.M., Marino, L.D. and Weaver, K.M. (2002), "Assessing the psychometric properties of the entrepreneurial orientation scale: a multi-country analysis", Entrepreneurship Theory and Practice, Vol. 26 No. 4, pp. 71-93.

Kropp, F., Lavack, A.M. and Silvera, D.H. (2005), "Values and collective self-esteem as predictors of consumer susceptibility to interpersonal influence among university students", International Marketing Review, Vol. 22 No. 1, pp. 7-33.

Kropp, F., Lindsay, N.J. and Shoham, A. (2006), "Entrepreneurial, market, and learning orientations and international entrepreneurial business venture performance in South African firms", International Marketing Review, Vol. 23 No. 5, pp. 504-523.

Kropp, F., Lindsay, N.J. and Shoham, A. (2008), "Entrepreneurial orientation and international entrepreneurial business venture startup", International Journal of Entrepreneurial Behavior and Research, Vol. 14 No. 2, pp. 102-117.

Krueger, N.F. and Carsrud, A.L. (1993), "Entrepreneurial intentions: applying the theory of planned behaviour", Entrepreneurship and Regional Development, Vol. 5 No. 4, pp. 315-330.

Lindsay, N.J. and Kropp, F. (2015), "Values and entrepreneurial orientation of early stage entrepreneurs", in Campbell, C. (Ed.), Marketing in Transition: Scarcity, Globalism, and Sustainability, Developments in Marketing Science: Proceedings of the Academy of Marketing Science, Springer, Cham, pp. 101-105.

Lindsay, N., Lindsay, W. and Kropp, F. (2008), "Values, attitudes, and start-up intentions of necessitybased nascent entrepreneurs", Frontiers of Entrepreneurship Research, Vol. 28 No. 5, p. 6.

Locke, E.A., Frederick, E., Lee, C. and Bobko, P. (1984), "Effect of self-efficacy, goals, and task strategies on task performance", Journal of Applied Psychology, Vol. 69 No. 2, pp. 241-251. 
IJM

42,2

Low, M.B. and MacMillan, I.C. (1988), "Entrepreneurship: past research and future challenges", Journal of Management, Vol. 14 No. 2, pp. 139-161.

Lumpkin, G.T. and Dess, G.G. (1996), "Clarifying the entrepreneurial orientation construct and linking it to performance", Academy of Management Review, Vol. 21 No. 1, pp. 135-172.

Lumpkin, G.T. and Dess, G.G. (2001), "Linking two dimensions of entrepreneurial orientation to firm performance: the moderating role of environment and industry life cycle", Journal of Business Venturing, Vol. 16 No. 5, pp. 429-451.

Marino, L., Strandholm, K., Steensma, H.K. and Weaver, K.M. (2002), "The moderating effect of national culture on the relationship between entrepreneurial orientation and strategic alliance portfolio extensiveness", Entrepreneurship: Theory and Practice, Vol. 26 No. 4, pp. 145-161.

Matlay, H. (2008), "The impact of entrepreneurship education on entrepreneurial outcomes", Journal of Small Business and Enterprise Development, Vol. 15 No. 2, pp. 382-396.

McCline, R.L., Bhat, S. and Baj, P. (2000), "Opportunity recognition: an exploratory investigation of a component of the entrepreneurial process in the context of the health care industry", Entrepreneurship: Theory and Practice, Vol. 25 No. 2, p. 81.

McKee, D.O., Varadarajan, P.R. and Pride, W.M. (1989), "Strategic adaptability and firm performance: a market-contingent perspective", Journal of Marketing, Vol. 53 No. 3, pp. 21-35.

Migliori, S., Pittino, D., Consorti, A. and Lucianetti, L. (2017), "The relationship between entrepreneurial orientation, market orientation and performance in university spin-offs", The International Entrepreneurship and Management Journal, Vol. 15, pp. 793-814, doi: 10.1007/ s11365-017-0488-x.

Miller, D. (1983), "The correlates of entrepreneurship in three types of firms", Management Science, Vol. 29 No. 7 , pp. $770-791$.

Miller, P. and Bound, K. (2011), The Startup Factories: The Rise of Accelerator Programmes to Support New Technology Ventures, Nesta, London.

Munoz, L. (2010), "Forced to entrepreneurship: modeling the factors behind necessity entrepreneurship", Journal of Business and Entrepreneurship, Vol. 22 No. 1, pp. 37-53.

Narver, J.C. and Slater, S.F. (1990), "The effect of a market orientation on business profitability", Journal of Marketing, Vol. 54 No. 4, pp. 20-35.

Newbert, S.L., Tornikoski, E.T. and Quigley, N.R. (2013), "Exploring the evolution of supporter networks in the creation of new organizations", Journal of Business Venturing, Vol. 28 No. 2 , pp. 281-298.

Nummela, N., Saarenketo, S. and Loane, S. (2016), "The dynamics of failure in international new ventures: a case study of Finnish and Irish software companies", International Small Business Journal, Vol. 34 No. 1, pp. 51-69.

Parliamentary Joint Committee on Corporations and Financial Services (2013), Family Businesses in Australia - Different and Significant: Why They Shouldn't Be Overlooked, Commonwealth of Australia, Canberra.

Peterman, N.E. and Kennedy, J. (2003), "Enterprise education: influencing students' perceptions of entrepreneurship", Entrepreneurship Theory and Practice, Vol. 28 No. 2, pp. 129-144.

Podsakoff, P.M., MacKenzie, S.B., Lee, J.-Y. and Podsakoff, N.P. (2003), "Common method biases in behavioral research: a critical review of the literature and recommended remedies", Journal of Applied Psychology, Vol. 88 No. 5, pp. 879-903.

Podsakoff, P.M., MacKenzie, S.B. and Podsakoff, N.P. (2012), "Sources of method bias in social science research and recommendations on how to control it", Annual Review of Psychology, Vol. 63 No. 1, pp. 539-569.

Rauch, A., Wiklund, J., Lumpkin, G.T. and Frese, M. (2009), "Entrepreneurial orientation and business performance: an assessment of past research and suggestions for the future", Entrepreneurship Theory and Practice, Vol. 33 No. 3, pp. 761-787. 
Robinson, P.B., Stimpson, D.V., Huefner, J.C. and Hunt, H.K. (1991), "An attitude approach to the prediction of entrepreneurship", Entrepreneurship: Theory and Practice, Vol. 15 No. 4, pp. 13-31.

Rokeach, M. (1973), The Nature of Human Values, Free Press, New York.

Romano, C.A., Tanewski, G.A. and Smyrnios, K.X. (2001), "Capital structure decision making: a model for family business", Journal of Business Venturing, Vol. 16 No. 3, pp. 285-310.

Roos, G. and O'Connor, A. (2015), Integrating Innovation: South Australian Entrepreneurship Systems and Strategies, University of Adelaide Press, Adelaide, SA.

Rose, G.M. and Shoham, A. (2002), "Export performance and market orientation: establishing an empirical link", Journal of Business Research, Vol. 55 No. 3, pp. 217-225.

Rosenberg, D. (2002), Cloning Silicon Valley : The Next Generation High-Tech Hotspots, Pearson Education, London.

Sarasvathy, S.D. (2001), "Causation and effectuation: towards a theoretical shift from economic inevitability to entrepreneurial contingency", Academy of Management Review, Vol. 26 No. 2, pp. 243-288.

Saxenian, A. (1994), Regional Advantage : Culture and Competition in Silicon Valley and Route 128, Harvard University Press, Cambridge, MA.

Scarato, M. (2018), Search Funds: An European Perspective and an Italian Market Analysis, University of Padua, Padova.

Schindehutte, M. and Morris, M.H. (2009), "Advancing strategic entrepreneurship research: the role of complexity science in shifting the paradigm", Entrepreneurship Theory and Practice, Vol. 33 No. 1, pp. 241-276.

Schumpeter, J.A. (1934), The Theory of Economic Development : An Inquiry into Profits, Capital, Credit, Interest, and the Business Cycle, Harvard University Press, Cambridge, MA.

Schwartz, S.H. and Bilsky, W. (1990), "Toward a theory of the universal content and structure of values: extensions and cross-cultural replications", Journal of Personality and Social Psychology, Vol. 58 No. 5, pp. 878-891.

Schwartz, R.G., Teach, R.D. and Birch, N.J. (2005), "A longitudinal study of entrepreneurial firms opportunity recognition and product development management strategies: implications by firm type", International Journal of Entrepreneurial Behavior and Research, Vol. 11 No. 4, pp. 315-329.

Seet, P.S., Jones, J., Oppelaar, L. and Corral de Zubielqui, G. (2018), "Beyond 'know-what' and 'knowhow' to 'know-who': enhancing human capital with social capital in an Australian start-up accelerator", Asia Pacific Business Review, Vol. 24 No. 2, pp. 233-260.

Shane, S.A. (2003), A General Theory of Entrepreneurship : The Individual-Opportunity Nexus, E. Elgar, Northampton, MA.

Shane, S. and Venkataraman, S. (2000), "The promise of entrepreneurship as a field of research", Academy of Management Review, Vol. 25 No. 1, pp. 217-226.

Shepherd, D.A. (2011), "Multilevel entrepreneurship research: opportunities for studying entrepreneurial decision making”, Journal of Management, Vol. 37 No. 2, pp. 412-420.

Shoham, A., Rose, G.M. and Kropp, F. (2005), "Consequences of a market orientation: a meta-analysis", Marketing Intelligence and Planning, Vol. 23 Nos 4-5, pp. 435-54.

Singer, S., Amorós, J.E. and Arreola, D.M. (2015), "Global entrepreneurship monitor: 2014 global report”, Global Entrepreneurship Research Association, pp. 1-116.

Sitkin, S.B. and Pablo, A.L. (1992), "Reconceptualizing the determinants of risk behavior", Academy of Management Review, Vol. 17 No. 1, pp. 9-38.

Steffens, P., Davidsson, P. and Fitzsimmons, J. (2006), "The performance of young firms: patterns of evolution in the growth - profitability space", Academy of Management Proceedings, pp. I1-I6. 
IJM

42,2

\section{4}

Stephan, U., Hart, M. and Drews, C.-C. (2015), Understanding Motivations for Entrepreneurship: a Review of Recent Research Evidence, Enterprise Research Centre, Birmingham.

Stevenson, H.H. and Carlos Jarillo, J. (1990), "A paradigm of entrepreneurship: entrepreneurial management”, Strategic Management Journal, Vol. 11 No. 5, p. 17.

Tanewski, G. and Carey, P. (2007), "Determinants of value adding business advice provided by external accountants to SME clients", in 52nd International Council for Small Business World Conference, Turku.

Timmons, J.A. and Spinelli, S. (2007), New Venture Creation: Entrepreneurship for the 21st Century, McGraw-Hill, Boston.

Todoli-Signes, A. (2017), "The 'gig economy': employee, self-employed or the need for a special employment regulation?", Transfer: Review of Labour and Research, Vol. 23 No. 2, pp. 193-205.

Trompenaars, A. and Hampden-Turner, C. (1998), Riding the Waves of Culture : Understanding Cultural Diversity in Global Business, McGraw Hill, New York, NY.

Tucker, L.R. and Lewis, C. (1973), "A reliability coefficient for maximum likelihood factor analysis", Psychometrika, Vol. 38 No. 1, pp. 1-10.

Ucbasaran, D., Westhead, P. and Wright, M. (2001), "The focus of entrepreneurial research: contextual and process issues", Entrepreneurship: Theory and Practice, Vol. 25 No. 4, p. 57.

Unger, J.M., Rauch, A., Frese, M. and Rosenbusch, N. (2011), "Human capital and entrepreneurial success: a meta-analytical review", Journal of Business Venturing, Vol. 26 No. 3, pp. 341-358.

Uy, M.A., Foo, M.-D. and Song, Z. (2013), "Joint effects of prior start-up experience and coping strategies on entrepreneurs' psychological well-being”, Journal of Business Venturing, Vol. 28 No. 5, pp. 583-597.

van der Zwan, P., Thurik, R., Verheul, I. and Hessels, J. (2016), "Factors influencing the entrepreneurial engagement of opportunity and necessity entrepreneurs", Eurasian Business Review, Vol. 6 No. 3, pp. 273-295.

Wales, W.J., Gupta, V.K. and Mousa, F.-T. (2013), "Empirical research on entrepreneurial orientation: an assessment and suggestions for future research", International Small Business Journal, Vol. 31 No. 4, pp. 357-383.

Wasserstein, A. (2017), Searching for a Search Fund Structure: A Student Takes a Tour of Various Options, Sage Publishing, London.

Welpe, I.M., Spörrle, M., Grichnik, D., Michl, T. and Audretsch, D.B. (2012), "Emotions and opportunities: the interplay of opportunity evaluation, fear, joy, and anger as antecedent of entrepreneurial exploitation”, Entrepreneurship Theory and Practice, Vol. 36 No. 1, pp. 69-96.

Welter, F., Baker, T., Audretsch, D.B. and Gartner, W.B. (2017), "Everyday entrepreneurship-a call for entrepreneurship research to embrace entrepreneurial diversity", Entrepreneurship Theory and Practice, Vol. 41 No. 3, pp. 311-321, doi: 10.1111/etap.12258.

Welter, F., Baker, T. and Wirsching, K. (2018), "Three waves and counting: the rising tide of contextualization in entrepreneurship research", Small Business Economics.

West, G.P. (2003), "Connecting levels of analysis in entrepreneurship research: a focus on information processing, asymmetric knowledge and networks", in Steyaert, C. and Hjorth, D. (Eds), New Movements in Entrepreneurship, Edward Elgar, London, pp. 51-70.

Wood, R. and Bandura, A. (1989), "Social cognitive theory of organizational management", Academy of Management Review, Vol. 14 No. 3, pp. 361-384.

Zahra, S.A. (1991), "Predictors and financial outcomes of corporate entrepreneurship: an exploratory study", Journal of Business Venturing, Vol. 6 No. 4, pp. 259-285.

Zahra, S.A., Jennings, D.F. and Kuratko, D.F. (1999), "The antecedents and consequences of firm-level entrepreneurship: the state of the field", Entrepreneurship: Theory and Practice, Vol. 24, pp. 47-67. 
Zhao, H., Seibert, S.E. and Hills, G.E. (2005), "The mediating role of self-efficacy in the development of entrepreneurial intentions", Journal of Applied Psychology, Vol. 90 No. 6, pp. 1265-1272.

Zou, S., Taylor, C.R. and Osland, G.E. (1998), "The EXPERF scale: a cross-national generalized export performance measure", Journal of International Marketing, Vol. 6 No. 3, pp. 37-58.

\section{About the authors}

Pi-Shen Seet is Professor of Entrepreneurship and Innovation and Deputy Director of the Centre of Work and Organisational Performance at the School of Business and Law, Edith Cowan University, Australia. His current research interests include social entrepreneurship, knowledge-based innovation, entrepreneurial decision making and family business succession strategies. Pi-Shen Seet is the corresponding author and can be contacted at: p.seet@ecu.edu.au

Noel Lindsay is Pro Vice Chancellor - Entrepreneurship and Dean of Business, Adelaide Business School at the University of Adelaide. His research interests include business/social entrepreneurship with particular focus on how entrepreneurship can empower communities and those who are disadvantaged.

Fredric Kropp is Emeritus Professor of Entrepreneurship, Creativity and Innovation at the Middlebury Institute of International Studies. He has expertise in entrepreneurship, social entrepreneurship, marketing, and creativity and innovation. He is an active researcher in the area of social entrepreneurship and necessity-based entrepreneurship. He recently was a Fulbright Scholar studying social entrepreneurship in Ireland.

\section{Understanding early-stage firm \\ performance}

\section{5}

For instructions on how to order reprints of this article, please visit our website:

www.emeraldgrouppublishing.com/licensing/reprints.htm

Or contact us for further details: permissions@emeraldinsight.com 